\title{
THE ROLE OF CUSTOMER TRUST, SERVICE QUALITY AND VALUE DIMENSIONS IN DETERMINING SATISFACTION AND LOYALTY: AN EMPIRICAL STUDY OF MOBILE TELECOMMUNICATION INDUSTRY IN PAKISTAN
}

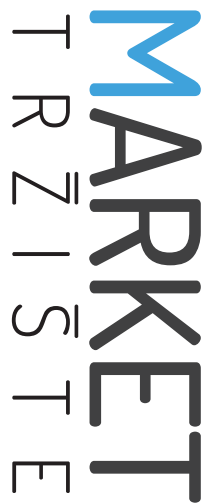

\section{ULOGA POTROŠAČEVA POVJERENJA, KVALITETE USLUGE I DIMENZIJA VRIJEDNOSTI PRI ODREĐIVANJU ZADOVOLJSTVA I LOJALNOSTI: EMPIRIJSKO ISTRAŽIVANJE MOBILNE TELEKOMUNIKACIJSKE INDUSTRIJE U PAKISTANU}

Market-Tržište

Vol. 30, No. 2, 2018, pp. 177-194

UDK 366.1:654.165

D0I http://dx.doi.org/10.22598/mt/2018.30.2.177

Original scientific paper

\footnotetext{
Wajeeha Aslama , Imtiaz Arifb, Kashif Farhatc, Marium Khursheed ${ }^{d}$

a) IQRA University, Abid Town, Block 2, Gulshan e Iqbal, Karachi, PAKISTAN, e-mail: wajeeha_aslam_87@live.com

b) IQRA University, Abid Town, Block 2, Gulshan e lqbal, Karachi, PAKISTAN, e-mail: arif.i@iuk.edu.pk

c) Muhammad Ali Jinnah University, Shahra-e-Faisal, 75300 - Karachi, PAKISTAN, e-mail: kashif.farhat@gmail.com

d) IQRA University, Abid Town, Block 2, Gulshan e Iqbal, Karachi, PAKISTAN, e-mail: mariumkhursheed@gmail.com
}

\section{Abstract}

Purpose - The primary purpose of this study is to investigate the factors which influence customer satisfaction and customer loyalty in telecommunication services. Customer satisfaction and loyalty are considered to be major components ensuring effectiveness and growth in the services industry.

Design/Methodology/Approach - The data of 406 respondents was gathered via an adapted questionnaire. The statistical techniques of reliability analysis, explor-

\section{Sažetak}

Svrha - Primarna je svrha ovoga istraživanja ispitati i istražiti čimbenike koji utječu na zadovoljstvo i lojalnost potrošača telekomunikacijskim uslugama jer se oni smatraju glavnim komponentama za osiguranje učinkovitosti i rasta $u$ industriji usluga.

Metodološki pristup - Prikupljeni su podatci od 406 ispitanika putem prilagođenog upitnika. Statističke tehnike: analiza pouzdanosti, eksploratorna faktorska analiza (EFA), konfirmatorna faktorska ana- 
atory factor analysis (EFA), confirmatory factor analysis (CFA), and SEM Path analysis were employed to test the hypotheses.

Findings and implications - The findings of the research study show that trust and satisfaction have a significant impact on customer loyalty, with satisfaction holding a strong position. Trust and service quality have a significant impact on customer satisfaction. Also, from the point of view of perceived value, emotional value and monetary value are significantly correlated to customer satisfaction. According to TRA, this shows that positive consumer attitude leads towards a strong intention to fulfil their belief.

Limitations - The sample of the study may be one of the limitations. Cross-cultural comparison may be conducted in future to identify the differences among the cultures. Also, comparison between developed and under-developed countries may provide holistic results.

Originality - The study focused on an examination of customer satisfaction and loyalty on the basis of perceived value determinants, trust, and service quality.

Keywords - customer satisfaction, customer loyalty, trust, service quality, perceived value liza (CFA) i SEM Path analiza korištene su radi testiranja hipoteza.

Rezultati i implikacije - Rezultati istraživanja pokazali su da povjerenje i zadovoljstvo imaju značajan utjecaj na lojalnost potrošača, a zadovoljstvo snažnu poziciju. Povjerenje i kvaliteta usluge imaju značajan utjecaj na zadovoljstvo potrošača. Isto tako, kad je u pitanju konstrukt percipirane vrijednosti, emocionalna vrijednost $\mathrm{i}$ novčana vrijednost značajno su povezane sa zadovoljstvom potrošača. Prema TRA-u, to pokazuje da pozitivan stav potrošača vodi prema snažnoj namjeri ispunjavanja njegova uvjerenja.

Ograničenja - Uzorak istraživanja može biti jedno od ograničenja. U budućnosti se može provesti međukulturalna usporedba kako bi se vidjele razlike između kultura. Usporedba razvijenih i nedovoljno razvijenih zemalja isto tako može pružiti holističke rezultate.

Doprinos - Istraživanje je usmjereno na razmatranje zadovoljstva i lojalnosti potrošača na temelju percipiranih odrednica vrijednosti, povjerenja i kvalitete usluge.

Ključne riječi - zadovoljstvo potrošača, lojalnost potrošača, povjerenje, kvaliteta usluge, percipirana vrijednost 


\section{INTRODUCTION}

We live in a technology-oriented world which has seen a phase of rapid development. Nowadays, the world is considered a global village (Friedrich, Grone, Holbling \& Peterson, 2009; Aslam, Ham \& Arif, 2017), in which everyone wants to connect to the other person (Hudson, 2013). Technological advancements have changed the way we consume, distribute, and create information (Arif, Aslam \& Ali, 2016; Aslam, Batool \& Haq, 2016). As is the case with developed countries, Pakistan also placed itself in the fast-moving technological race and has been cited as an emerging market in mobile phones penetration (Qayyum, Ba Khang \& Krairit, 2013). The telecom sector of Pakistan has emerged as a key factor in the growth of the economy (Jahanzeb, Fatima \& Khan, 2011) as it contributed revenue of PKR 454.4 billion by the end of FY 2015-2016. It also constituted $26 \%$ of the total revenue of the country, as stated in the annual report of the Pakistan Telecommunication Authority (PTA) for 2016. According to Shujaat, Syed and Ahmed (2015), telecommunications is an immensely governed sector, rapidly making headway to keep up with the initiatives of global markets. As stated in the United Nations Conference on Trade and Development (UNCTAD) Information Economy Report 2009, Pakistan ranked fifth by growth and expansion of the cellular market in the world. The cellular market of Pakistan is among the rapidly growing markets which have a higher rate of growth than other sectors in the country (Ali et al., 2010). According to the 2016 PTA annual report, the cellular density of Pakistan had risen from $60.72 \%$ to $69.12 \%$, with a total of 133.24 million cellular subscribers in the country. Moreover, the mobile broadband (3G \& 4G) penetration also increased to $15.32 \%$ and the number of $3 G$ and $4 G$ subscribers reached 29.53 million. Pakistan has five cellular service providers - Mobilink, Warid, Ufone, Telenor, and (CMpak) Zong - competing intensely for a bigger market share and more revenue.

This great expansion of the mobile telecommunication services market in Pakistan intensifies the need to determine customer loyalty as the Pakistani cellular market of Pakistan has now reached its maturity stage. All service providers aim to satisfy customers, gain their trust, and prevent them from switching to other options (Gerpott, Rams \& Schindler, 2001) by providing competitive quality services which include call quality, network issue, Internet packages, and SMS packages. According to Santouridis and Trivellas (2010), to retain their customers, businesses should adhere to the services that are perceived as being more beneficial than having to obtain and search for new ones. Customers who are loyal have a lower switching tendency and they are not prone to trying alternative market offers very often. Additionally, they also generate positive word of mouth. Customer loyalty is extremely important and has gained significance in the telecommunication service industry due to the competitive nature of the market (Gerpott et al., 2001). It has been observed that, in order to measure the loyalty of customers, other variables such as satisfaction have gained substantial attention in the marketing literature (Aydin, Özer \& Arasil, 2005; Lai, Griffin \& Babin, 2009). According to Deng, Lu, Wei and Zhang (2010), satisfaction is an important intermediate goal towards achieving economic success in mobile telecommunications. And according to Kassim and Abdullah (2008), satisfaction is not sufficient to preserve longterm relationship with the service provider. Hart and Johnson (1999) and Aydin and Özer (2006) argued that to gain the loyalty of the customers, trust is an essential driver.

In the past, Rasheed and Abadi (2014), Ball, Simões Coelho and Machás (2004), Luarn and Lin (2003) and Kim, Ferrin and Rao (2009) examined customer loyalty in various service industries. These studies highlighted loyalty as a critical factor to consider in terms of the customers' perspective. Ishaq (2012), Rust, Lemon and Zeithaml (2001), and Ali and others (2010) asserted that, in telecommunication services, loyalty is the most crucial performance benchmark to obtain. 
The growth rate in the mobile telecommunications industry is reported to be phenomenal in recent years, and has caused the market to become very competitive (Qayyum et al., 2013). Owing to the growing importance of the telecommunications industry, this paper predominantly analyzes the behavior of consumers in adopting the services of different cellular service providers in Pakistan. Primarily, this research examines the effects of trust, customer perceived value constructs, and service quality upon satisfaction which leads to loyalty. The findings of the study can help marketing practitioners as it represents a notable contribution to the knowledge of customer loyalty and satisfaction.

This paper comprises the following section: after this Introduction, Section 2 deals with the theoretical background and hypothesis development of the study; the research methodology, including sample size, development of instruments, data collection procedures, and statistical techniques are reported in Section 3; Section 4 covers the findings of the study while Section 5 presents the conclusion, implications, and limitations of the study.

\section{THEORETICAL BACKGROUND AND HYPOTHESES DEVELOPMENT}

\subsection{Conceptual framework}

Few researchers have adopted the framework of Theory of Reasoned Action (TRA) to measure customer loyalty and satisfaction in the services industry. Also, few researchers used Theory of Planned Behavior (TPB), as an extended form in which perceived behavioral control has been added to TRA. TRA presented by Fishbein and Ajzen (1975) provides a model to investigate the relationship between behaviors, intention, and attitude in social psychology (Hansen, Jenses \& Solgaard, 2004). Fishbein and Ajzen (1975) argued that the behavioral intentions are functionally related by attitudes, which forecast the desired behavior. Moreover, TRA considered intention as the best predictor of behavior (Kim et al., 2009). According to TRA, proposed intention leads to certain behaviors, such as satisfaction and loyalty. According to Chang (1998), Fishbein and Ajzen (1975), Guo, Xiao and Tang (2009), and Hsu and Lu (2007), the attitude towards the consumer behavior, which can be favorable or unfavorable feelings and subject norms, i.e. belief about what others will think about behavior, are the main antecedents that may provoke behavioral intentions (likelihood of performing the behavior). As reported by literature on consumer behavior, personal opinion and attitude are developed from consumer's personal experience of things and objects (Karjaluoto, Mattila \& Pento, 2002). Hence, TRA theory helps in identifying the consumer behavior and intention to generate customer loyalty. If consumer behavior regarding quality, trust of service, and perceived value of customers is favorable, it will lead to customer satisfaction. According to Guo and others (2009), satisfaction influences the attitude and customer loyalty. In addition to that, several researchers such as Luarn and Lin (2003) and Lin and Wang (2006) viewed trust as a trusting belief which leads to a trusting attitude that precedes behaviors. Lu and Lin (2002) and Lin and Wang (2006) also showed that belief that can be trust also influenced behavior directly as well as that mediated by attitude/intention. On the basis of TRA and TPB, the research model has been designed (see Figure 1).

\subsection{Customer satisfaction and loyalty}

Satisfaction depicts customer post-purchase evaluation and an effective response towards the overall service or product attributes (Lin \& Wang, 2006; Anderson, Fornell \& Lehmann, 1994). According to Kotler, Keller, Koshy and Jha (2009), satisfaction is a feeling that consumers experience after consuming a product or service. Customer satisfaction is often considered an important determinant of customer loyalty and repurchase intention (Deng et al., 2010; Liao, Palvia \& Chen, 2009). It also serves as an indica- 
tor of customers' positive and negative feelings about the service provider in the telecommunication services sector (Moreira et al., 2016). Studies confirmed that satisfaction leads to loyalty, which means that satisfied customers become loyal whereas dissatisfied customers move to other service providers (John, 2011). According to Moreira and others (2016), customer satisfaction is an important construct in loyalty. It is necessary for the telecommunication companies to keep the focus on their customers' view. Customer satisfaction has emerged as a strong predictor of loyalty in sizeable mobile telecommunication literature (Gerpott et al., 2001; Kim, Park \& Jeong, 2004; Lee \& Turban, 2001). Hence, the first hypothesis of the study is:

H1: Customer satisfaction has a positive impact on customer loyalty.

\subsection{Importance of trust}

In electronic commerce, winning consumer trust is often a matter of concern for marketers. McKnight and Chervany (2002) and Deng and others (2010) stated that trust can be considered as belief and also as an intention. Belief refers to the user's perception of attributes of service providers, such as ability, integrity, and benevolence. Intention, on the other hand, refers to the truster's willingness or intention to depend on the trustee. In mobile and electronic commerce, customers cannot fully regulate the business; therefore, it is necessary for the service provider not to engage in any unfair behavior (Gefen, 2002). As trust is an important factor in building and maintaining relationships, it is considered the main element of success in electronic commerce (Lee \& Turban, 2001) and in mobile social commerce (Siau \& Shen, 2003). According to Morgan and Hunt (1994), trust plays a critical role in developing such a relationship with customers which leads to loyalty. Many researches labeled trust positively as the backbone of a long-term relationship with customers and also considered it a driver of strong customer loyalty (Garbarino \& Johnson, 1999; Sirdeshmukh, Singh \& Sabol, 2002). Customers who trust in an orga- nization are more likely to be loyal to the company. Based on the theory of reasoned action, it is expected that trust precedes the loyalty.

According to Kassim and Abdullah (2008), customer satisfaction and loyalty increase when customers trust their service provider. In other words, if a customer does not trust the service provider, that consumer will undoubtedly be dissatisfied with the service provider. Theory of reasoned action also posits that trust leads to satisfaction which, in turn, increases loyalty. According to Kim and others (2009), trust affects satisfaction in the long run. If customers have feelings of faith in the service provider, their satisfaction will enhance over the time (Chiou \& Droge, 2006). Customer trust is the main factor in building loyalty (Deng et al., 2010). If customers trust the service provider, they continue using the service and also recommend it to others in their social circle. According to Lee (2005) and Wang, Lin and Luarn (2006), in mobile commerce, trust positively influences customer attitude and behavioral intention. Rasheed and Abadi (2014) also found a positive relationship between trust and customer satisfaction. Hence, the following hypotheses are formulated:

H2: Trust has a positive impact on customer loyalty.

H3: Trust has a positive impact on customer satisfaction.

\subsection{Perceived service quality and customer satisfaction}

According to Qayyum and others (2013), service quality is referred to as the customer judgment about the overall performance excellence and maintenance of the service. Service quality is one of the important determinants of examining the customer experience of the service (Khan \& Fasih, 2014). Higher service quality increases the satisfaction of purchasing the same product and affects the buying behavior of the customers (Venetis \& Ghauri, 2000). However, service quality is extremely important for survival and battle with competitors (Kyoon Yo \& Ah Park, 2007). 
Service quality is viewed as a strong predictor of customer satisfaction, as it relates to the overall efficiency of service providers (Kim et al., 2004). According to Gitomer (1998), customer satisfaction is attained by providing the up-to-mark service that also meets expectations. Based on these views, the following hypothesis is formed:

H4: Service quality has a positive impact on customer satisfaction.

\subsection{Customer value and customer satisfaction}

According to Sweeny and Soutar (2001), customer value is basically a concept which includes many heterogeneous factors. Sheth, Newman and Gross (1991) argued that a customer's choice during purchase is triggered by many factors; for that they developed several value dimensions, including functional value, conditional value, social value, emotional value, and epistemic value. According to Parasuraman and Grewal (2000), perceived value is a function of the 'get' component, i.e. benefits a buyer derives from a seller's offerings, and of the 'give' component, i.e. buyer's monetary and non-monetary cost of acquiring the offerings. Perceived value can be related to customer satisfaction (Sweeny $\&$ Soutar, 2001). Different aspects of perceived customer value have impact upon satisfaction; for instance, functional value relates to the overall service and technical benefits, emotional value fulfills the psychological need, monetary value is related to the price and time, and social value is connected to consumers socially (Karjaluoto, Jayawardhena, Leppäniemi \& Pihlström, 2012; Deng et al., 2010; Sweeny \& Saoutar, 2001). Perceived value also regulates satisfaction in a favorable manner, and satisfaction is derived from customer value (Deng et al., 2010). We have used four dimensions of perceived value to form the following hypotheses:

H5a: Functional value has a positive impact on customer satisfaction.

H5b: Emotional value has a positive impact on customer satisfaction.

H5c: Social value has a positive impact on customer satisfaction.

H5d: Monetary value has a positive impact on customer satisfaction.

FIGURE 1: The research model

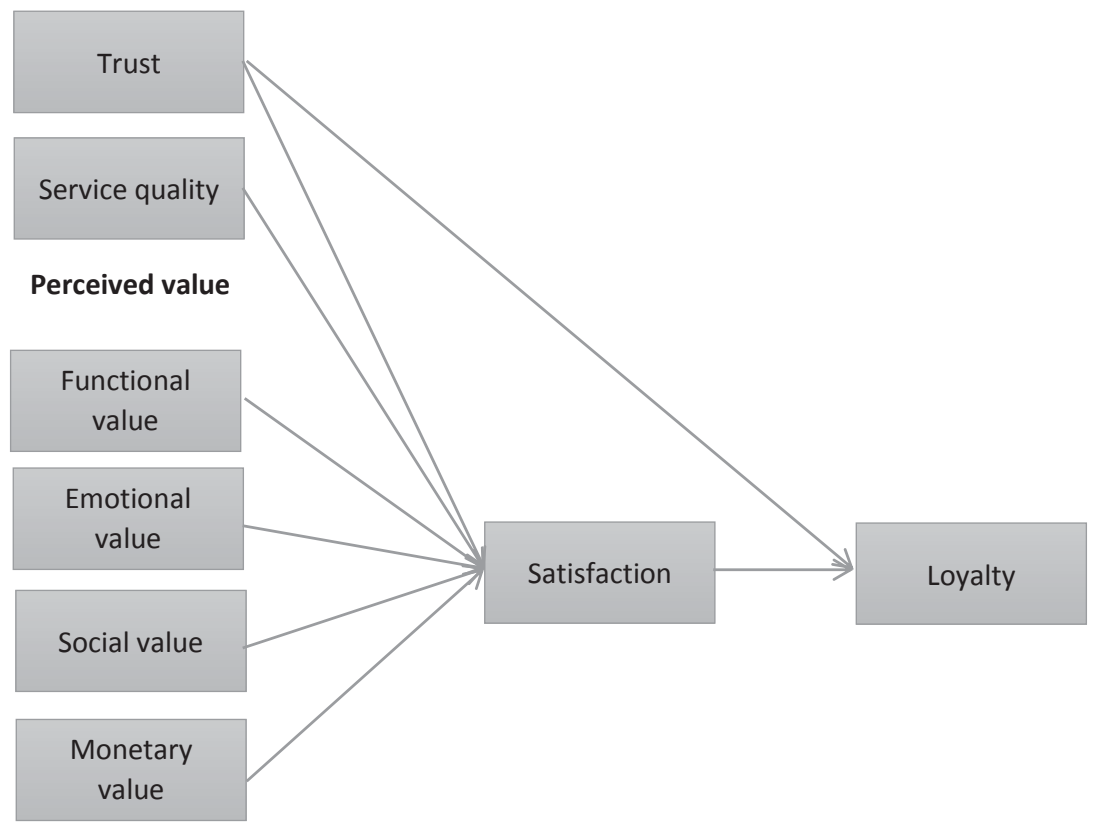




\section{METHODOLOGY}

\subsection{Instrument development}

This study used an adapted 5-point Likert scale questionnaire, in which 1 represents "strongly disagree" and 5 represents "strongly agree." The questionnaire consisted of two parts: the first part was related to the demographic profile of respondents and concerned their cellular service usage; whereas the second part dealt with the constructs. Most items of the constructs were adapted from Deng and others (2010), with some added questions related to the past studies mentioned in Table 4.2. The purpose behind such a design of the questionnaire was to acquire useful information related to the topic.

Functional value consists of a total of 4 items, which were modified from Sweeny and Sautor (2001) and Deng and others (2010).

Emotional value is covered by 4 items, which were adapted from the research of Sweeny and Sautor (2001) and Deng and others (2010).

Social value is evaluated by 4 items, designed upon the research of Sweeny and Sautor (2001) and Deng and others (2010).

Monetary value is measured by 4 items, adapted from the sources of Sweeny and Sautor (2001) and Deng and others (2010).

Perceived service quality covers 4 items, which were revised from the research of Deng and others (2010) and Qayyum and others (2013).

Trust consists of 4 items, which were modified from the work of Deng and others (2010) and Qayyum and others (2013).

Customer satisfaction is measured by 4 items, designed from the past papers of Lin and Wang (2006) and Deng and others (2013).

Customer loyalty consists of 4 items, which were adapted from the research of Lin and Wang (2006), Deng and others (2010), and Qayyum and others (2013).

\subsection{Sample frame and data collection procedure}

The data was collected from the mobile subscribers with the help of the adapted questionnaire. The use of questionnaires in gathering the responses is a cost-effective method of collecting a large amount of information so as to generate results quickly in a short time span. In total, data of 406 respondents was gathered via an online Google survey form and via handouts given to the respondents in person. During the data screening stage, 22 outliers were found, in which 20 were univariate and 2 were multivariate outliers. Multivariate outliers were found by analyzing the absolute Z-score value 3.29 and the Mahalanobis distance value, along with the Chi-square distribution function having the value of $p<0.001$ (Tabachnick \& Fidell, 2007). After the removal of outliers, 384 responses were used in further analysis.

\subsection{Statistical techniques}

A number of statistical tests were used, including exploratory factor analysis (EFA), confirmatory factor analysis (CFA) and Structural Equation Modeling (SEM). EFA was employed to align the constructs, with CFA applied for confirmation of the factors. Lastly, SEM was used because it allows checking all the variables in the model simultaneously (Chin, 1998). SEM analysis would also help in the measurement error reduction by using CFA (Fornell \& Larcker, 1981). This means that the relationship among examined factors is free of measurement errors.

\section{DATA ANALYSIS AND RESULTS}

IBM SPSS 22 (Statistical Package for social sciences) and IBM Amos 22 (analysis of moment structure) were used to analyze the data. The data of 384 respondents was used to explore factors by means of principal component extraction, along with Varimax orthogonal rotation. Furthermore, the reliability of the factor loading items, which should be a minimum 0.7 value of the Cronbach alpha (Nunnally, 1978), was determined. After ex- 
ploring the factors, CFA was performed to analyze composite reliability (CR), maximum reliability (Max R), model fitness and validation concerns, which involved the average variance extracted (AVE), discriminant validity, and construct validity. After that, SEM path analysis was performed to check correlations among the constructs.

\subsection{Demographic profile of respondents}

TABLE 4.1: Demographic profile of respondents

\begin{tabular}{|c|c|c|}
\hline & Frequency & Percentage \\
\hline \multicolumn{3}{|l|}{ Gender } \\
\hline Male & 170 & 44.3 \\
\hline Female & 214 & 55.7 \\
\hline \multicolumn{3}{|l|}{ Age } \\
\hline $18-23$ & 50 & 13 \\
\hline $24-29$ & 182 & 47.4 \\
\hline $30-35$ & 89 & 23.2 \\
\hline $36-40$ & 42 & 10.9 \\
\hline $40 \&$ above & 21 & 5.5 \\
\hline \multicolumn{3}{|l|}{ Qualification } \\
\hline Undergraduate & 44 & 11.5 \\
\hline Graduate & 265 & 69 \\
\hline $\begin{array}{l}\text { Postgraduate \& } \\
\text { Above }\end{array}$ & 75 & 19.5 \\
\hline
\end{tabular}

\section{Cellular service}

\begin{tabular}{|l|c|c|}
\hline Mobilink & 41 & 10.7 \\
\hline Telenor & 167 & 43.5 \\
\hline Ufone & 121 & 31.5 \\
\hline Warid & 23 & 6 \\
\hline Zong & 32 & 8.3 \\
\hline Years of service use
\end{tabular}

\section{Years of service use}

\begin{tabular}{|l|c|c|}
\hline Less than 1 year & 9 & 2.3 \\
\hline $1-2$ years & 27 & 7 \\
\hline 2-3 years & 132 & 34.4 \\
\hline More than 3 years & 215 & 56 \\
\hline
\end{tabular}

Table 4.1 shows the demographic details of 384 respondents. It clearly demonstrates that more than a half of the responses, i.e. $55.73 \%$, were those of females while males were represented at $44.27 \%$. Most of the respondents or $47.40 \%$ were in the 24-29 age bracket and the majority of the respondents, i.e. $69.01 \%$, had bachelor level education. This showed that respondents were mature enough to understand and answer the questions regarding each construct. The contribution of Telenor customers was among the highest at $43.49 \%$. Most respondents had been using cellular service for more than 3 years; that group has a contribution of $55.99 \%$, followed by those with 2-3 years of use, i.e. $34.38 \%$.

\subsection{Exploratory factor analysis (EFA) and confirmatory factor analysis (CFA)}

EFA was used while keeping a check on varimax rotation. All 32 variables items were reduced and loaded in their desired 8 components. Three items were deleted in adjusting rotated component matrix; hence 29 items remained for further analysis. The KMO value was 0.784 and communalities higher than 0.5. Both of these values confirm that the research model is suitable for further analysis. According to Tabachnick and Fidell (2007), Bartlett's test of sphericity and Kaiser-Meyer-Olkin (KMO) value should be a minimum 0.6. All factor loadings should be greater than 0.5 (Hair, Anderson, Babin \& Black, 2010; Tabachinek $\&$ Fidell, 2007). All of these values loaded above the required threshold for this study. Total reliability of 29 items was found at 0.732 . According to Nunnally (1978), the reliability of each construct should have a minimum cut-off value of 0.7 .

After EFA, CFA was also performed. One item of customer satisfaction was removed to obtain the optimum model fit. The overall measurement model validity and reliability were also assessed by performing CFA. Validity concerns for the measurement model were checked in CFA by using the "Master Validity Tool" Amos plugin. The validity of the factors is necessary to test the causal model. It denotes the strength of the measurement model (Rajan \& Baral 2015; Hair, Anderson, Tatham \& Black, 1998). The value of composite reliability should be greater than 0.7 and average variance extracted (AVE) should be above 0.5 (Bagozzi \& Yi, 1988). All the values of composite reliability loaded above the threshold 
value and fell in the range of 0.70 to 0.86 . Convergent validity of the model established as AVE values ranged from 0.41 to 0.62 , which meets the suggested threshold (Molina, Llorens-Montes \& Ruiz-Moreno, 2007; Castaño, Méndez \& Galindo, 2015; Dehghan, Alizadeh \& Mirzaei-Alamouti, 2015). The AVE value should exceed 0.5, but even less than 0.5 is acceptable where the Cronbach alpha and composite reliability values are greater than 0.7 (Fornell \& Larcker, 1981; Muhammad, Shamsudin \& Hadi, 2016; Mahjoub \& Naeij, 2015; Huang, Wang, Wu \& Wang, 2013; Chinomona \& Pretorius, 2011). Table 4.2 shows the factor loadings of EFA, CFA, Cronbach alpha, CR and AVE.

\section{TABLE 4.2: EFA and CFA}

\begin{tabular}{|c|c|c|c|}
\hline Items & $\begin{array}{c}\text { EFA } \\
\text { loadings }\end{array}$ & $\begin{array}{c}\text { CFA } \\
\text { loadings }\end{array}$ & $\begin{array}{l}\text { Adapted from } \\
\text { source }\end{array}$ \\
\hline \multicolumn{4}{|l|}{ Functional value $($ Cronbach alpha $=0.837 ; C R=0.841 ; A V E=0.64)$} \\
\hline My service provider is reliable. & 0.868 & 0.824 & \multirow{3}{*}{$\begin{array}{l}\text { Deng et al. (2010); } \\
\text { Sweeny \& Sautor } \\
(2001)\end{array}$} \\
\hline My service provider has good functions. & 0.873 & 0.864 & \\
\hline My service provider fulfils my needs well. & 0.814 & 0.704 & \\
\hline \multicolumn{4}{|l|}{ Emotional value (Cronbach alpha $=0.760 ; C R=0.777 ; A V E=0.478)$} \\
\hline I feel good when I use this service provider. & 0.723 & 0.852 & \multirow{4}{*}{$\begin{array}{l}\text { Sweeny \& Sautor } \\
\text { (2001), Deng et al. } \\
(2010)\end{array}$} \\
\hline Using this service provider is enjoyable. & 0.788 & 0.562 & \\
\hline This service provider gives me pleasure. & 0.775 & 0.493 & \\
\hline Using this service provider is interesting. & 0.647 & 0.794 & \\
\hline \multicolumn{4}{|l|}{ Social value (Cronbach alpha $=0.803 ; C R=0.804 ; A V E=0.506)$} \\
\hline My service provider helps me to feel acceptable. & 0.731 & 0.669 & \multirow{4}{*}{$\begin{array}{l}\text { Deng et al. (2010), } \\
\text { Sweeny \& Sautor } \\
(2001)\end{array}$} \\
\hline My service provider makes a good impression on other people. & 0.799 & 0.743 & \\
\hline Using my service provider gives me a sense of belongings to other users. & 0.798 & 0.692 & \\
\hline My service provider improves the way I am perceived. & 0.798 & 0.74 & \\
\hline \multicolumn{4}{|l|}{ Monetary value $($ Cronbach alpha $=0.876 ; C R=0.869 ; A V E=0.624)$} \\
\hline My service provider is reasonably priced. & 0.828 & 0.769 & \multirow{4}{*}{$\begin{array}{l}\text { Deng et al. (2010), } \\
\text { Sweeny \& Sautor } \\
(2001)\end{array}$} \\
\hline The price of using my service provider is economical. & 0.829 & 0.771 & \\
\hline My service provider offers value for money. & 0.819 & 0.812 & \\
\hline My service provider is good for the current price level. & 0.768 & 0.807 & \\
\hline \multicolumn{4}{|c|}{ Perceived service quality (Cronbach alpha $=0.748 ; C R=0.733 ;$ AVE $=0.41$ ) } \\
\hline My service provider always delivers excellent overall service. & 0.718 & 0.719 & \multirow{4}{*}{$\begin{array}{l}\text { Deng et al. (2010), } \\
\text { Qayyum et al. (2013) }\end{array}$} \\
\hline The offerings of my service provider are of high quality. & 0.717 & 0.675 & \\
\hline My service provider delivers superior service in every way. & 0.802 & 0.616 & \\
\hline $\begin{array}{l}\text { The staff of my mobile operator treats me in a friendly manner when I } \\
\text { report a complaint. }\end{array}$ & 0.726 & 0.536 & \\
\hline \multicolumn{4}{|l|}{ Trust (Cronbach alpha $=0.787 ; C R=0.801 ; A V E=0.582)$} \\
\hline Based on my experience, I know my service provider cares about customers. & 0.855 & 0.903 & \multirow{3}{*}{$\begin{array}{l}\text { Deng et al. (2010), } \\
\text { Qayyum et al. (2013) }\end{array}$} \\
\hline Based on my experience, I know my service provider is not opportunistic & 0.681 & 0.56 & \\
\hline $\begin{array}{l}\text { My mobile operator is reliable because it is mainly concerned with } \\
\text { customers' interests. }\end{array}$ & 0.883 & 0.784 & \\
\hline \multicolumn{4}{|l|}{ Customer satisfaction (Cronbach alpha $=0.712 ; C R=0.763 ; A V E=0.521$ ) } \\
\hline My choice of this service provider is a wise one. & 0.747 & 0.777 & \multirow{4}{*}{$\begin{array}{l}\text { Deng et al. (2010), } \\
\text { Lin \& Wang (2006) }\end{array}$} \\
\hline I think I did the right thing when I subscribed to this service provider. & 0.738 & 0.776 & \\
\hline Overall, my feeling about this service provider is satisfactory. & 0.751 & 0.598 & \\
\hline This service provider has met my expectations well. & 0.594 & Deleted & \\
\hline \multicolumn{4}{|l|}{ Customer loyalty (Cronbach alpha $=0.753 ; C R=0.754 ; A V E=0.506)$} \\
\hline I will continue to use my service provider if any. & 0.797 & 0.736 & \multirow{3}{*}{$\begin{array}{l}\text { Lin \& Wang (2006), } \\
\text { Deng et al. (2010), } \\
\text { Qayyum et al. (2013) }\end{array}$} \\
\hline I will recommend to others to use this service provider. & 0.796 & 0.748 & \\
\hline $\begin{array}{l}\text { Even if my friends recommended another service provider, my } \\
\text { preference for this service provider would not change. }\end{array}$ & 0.802 & 0.645 & \\
\hline
\end{tabular}


Wajeeha Aslam, Imtiaz Arif, Kashif Farhat, Marium Khursheed

\subsection{Discriminant validity and model fit}

Table 4.3 provides data for the discriminant validity. Diagonal elements of the table represent the value of the square root of AVE that should be greater than its inter-construct correlation values and, hence, the established discriminant validity (Malhotra \& Dash, 2011; Jayanthi \& Rajandaran, 2017; Deng et al., 2010). The maximum reliability MaxR(H) value exceeds the suggested threshold of 0.7 (Hancock \& Muller, 2001). Table 4.3 shows the model validity.

Model fitness refers to the overall fitness of our measurement model and our structural model. Different measures would be used to check the goodness of fit (GoF) index. Table 4.4 shows that all values are in their acceptable region.

TABLE 4.3: Discriminant validity

\begin{tabular}{|l|c|c|c|c|c|c|c|c|c|c|}
\hline & MSV & MaxR(H) & MV & SV & EV & FV & SQ & CS & TR & CL \\
\hline $\begin{array}{l}\text { Monetary value } \\
\text { (MV) }\end{array}$ & 0.216 & 0.87 & $\mathbf{0 . 7 9}$ & & & & & & & \\
\hline Social value (SV) & 0.087 & 0.806 & $0.295^{* * *}$ & $\mathbf{0 . 7 1 1}$ & & & & & & \\
\hline $\begin{array}{l}\text { Emotional value } \\
\text { (EV) }\end{array}$ & 0.216 & 0.837 & $0.465^{* * *}$ & $0.190^{* *}$ & $\mathbf{0 . 6 9 2}$ & & & & & \\
\hline $\begin{array}{l}\text { Functional value } \\
\text { (FV) }\end{array}$ & 0.045 & 0.858 & $0.184^{* *}$ & 0.044 & $0.205^{* * *}$ & $\mathbf{0 . 8}$ & & & & \\
\hline $\begin{array}{l}\text { Service quality } \\
\text { (SQ) }\end{array}$ & 0.184 & 0.745 & $0.264^{* * *}$ & 0.046 & $0.103 \dagger$ & -0.066 & $\mathbf{0 . 6 4}$ & & & \\
\hline $\begin{array}{l}\text { Customer } \\
\text { satisfaction (CS) }\end{array}$ & 0.184 & 0.783 & $0.209^{* *}$ & -0.005 & $0.200^{* *}$ & $-0.212^{* *}$ & $0.422^{* * *}$ & $\mathbf{0 . 7 2 2}$ & & \\
\hline \begin{tabular}{l} 
Trust (TR) \\
\hline $\begin{array}{l}\text { Customer loyalty } \\
\text { (CL) }\end{array}$
\end{tabular} & 0.078 & 0.067 & $-0.279^{* * *}$ & -0.084 & $-0.153^{* *}$ & $-0.162^{* *}$ & $0.114 \dagger$ & $0.210^{* * *}$ & $\mathbf{0 . 7 6 3}$ & \\
\hline $\begin{array}{l}\text { Significance of correlations: } \\
+p<0.100^{* *} p<0.010 \\
{ }^{*} p<0.050^{* *} p<0.001\end{array}$ & 0.76 & $0.132^{*}$ & $-0.114 \dagger$ & 0.096 & $-0.110 \dagger$ & 0.021 & $0.291^{* * *}$ & $0.193^{* *}$ & $\mathbf{0 . 7 1 1}$ \\
\hline
\end{tabular}

TABLE 4.4: Model fit

\begin{tabular}{|l|c|c|c|}
\hline \multicolumn{1}{|c|}{ Absolute fit measures } & $\begin{array}{c}\text { Recommended } \\
\text { value }\end{array}$ & $\begin{array}{c}\text { Measurement } \\
\text { model }\end{array}$ & $\begin{array}{c}\text { Structural } \\
\text { model }\end{array}$ \\
\hline$X^{2}$ & & 481.859 & 496.314 \\
\hline Df & & 317 & 322 \\
\hline$X^{2} / d f$ & $<3^{\text {a }}$ & 1.52 & 1.541 \\
\hline Goodness-of-fit index (GFI) & $>0.90^{\text {a }}$ & 0.919 & 0.917 \\
\hline $\begin{array}{l}\text { Root mean square error of approximation } \\
\text { (RMSEA) with p close }\end{array}$ & $<0.05^{\text {b }}$ & $.037(1.000)$ & $.038(1.000)$ \\
\hline Adjusted goodness-of-fit index (AGFI) & $>0.80^{\text {a }}$ & 0.897 & 0.895 \\
\hline Normed fit index (NFI) & closer to $1^{c}$ & 0.883 & 0.88 \\
\hline Comparative fit index (CFI) & $>0.95^{a}$ & 0.956 & 0.953 \\
\hline Incremental fit index (IFI) & $>0.90^{a}$ & 0.957 & 0.954 \\
\hline Tucker-Lewis index (TLI) & $>0.90^{a}$ & 0.947 & 0.945 \\
\hline
\end{tabular}

Sources: a Bagozzi \& Yi (1988), b Browne \& Cudeck (1993), ' Bentler (1990), Allen, Hunter \& Zeng (2015) 


\subsection{Hypothesis testing}

After getting the model fitness, the structural model was established and the hypothesis of the model was checked by performing path analysis among the variables. Table 4.5 shows the relationship among factors, while Figure 2 represents the structural model.

TABLE 4.5: Hypothesis testing

\begin{tabular}{|l|l|c|c|c|c|}
\hline $\begin{array}{l}\text { Hypo- } \\
\text { thesis }\end{array}$ & Path & Coefficient & S.E. & CR & $p$ \\
\hline$H 1$ & $\mathrm{CS} \rightarrow \mathrm{CL}$ & 0.247 & 0.063 & 3.921 & $* * *$ \\
\hline $\mathrm{H} 2$ & $\mathrm{TR} \rightarrow \mathrm{CL}$ & 0.071 & 0.034 & 2.068 & 0.039 \\
\hline $\mathrm{H} 3$ & $\mathrm{TR} \rightarrow \mathrm{CS}$ & 0.12 & 0.037 & 3.259 & 0.001 \\
\hline $\mathrm{H} 4$ & $\mathrm{SQ} \rightarrow \mathrm{CS}$ & 0.42 & 0.09 & 4.652 & $* * *$ \\
\hline $\mathrm{H} 5(\mathrm{a})$ & $\mathrm{FV} \rightarrow \mathrm{CS}$ & -0.155 & 0.042 & -3.702 & $* * *$ \\
\hline $\mathrm{H} 5(\mathrm{~b})$ & $\mathrm{EV} \rightarrow \mathrm{CS}$ & 0.137 & 0.052 & 2.649 & 0.008 \\
\hline $\mathrm{H} 5(\mathrm{c})$ & $\mathrm{SV} \rightarrow \mathrm{CS}$ & -0.067 & 0.05 & -1.346 & 0.178 \\
\hline $\mathrm{H} 5(\mathrm{~d})$ & $\mathrm{MV} \rightarrow \mathrm{CS}$ & 0.13 & 0.061 & 2.135 & 0.033 \\
\hline${ }^{*} p<0.05$ & $* * p<0.01$ & $* * p<0.001$ & & & \\
\hline
\end{tabular}

All research constructs were found to significant. However, the effect of social value has an insignificant negative impact on customer satisfaction, which is not meaningful (Dehghan et al., 2015; Leelakulthanit \& Hongcharu, 2011; Loh, Ahmed, Kadir \& Alam, 2015; Williams \& Soutar, 2009; Deng et al., 2010). The negative path coefficients were found by many researchers who rejected the specified correlation (Chinomona, Masinge \& Sandada, 2014; Eid, 2011). A significant negative correlation was found to exist between functional value and customer satisfaction.

\subsection{Mediation}

Mediation is used to check the causation in the model. It explains the accurate understanding of an antecedent on the dependent variable. Mediator plays a vital role in this causation chain. The Baron and Kenny (1986) approach was used to check the mediation in the model, which states three types of mediation: full, partial and indirect. However, modern literature suggests that mediation is less nuanced; it may be present when an indirect effect shows significant

FIGURE 2: Structural model

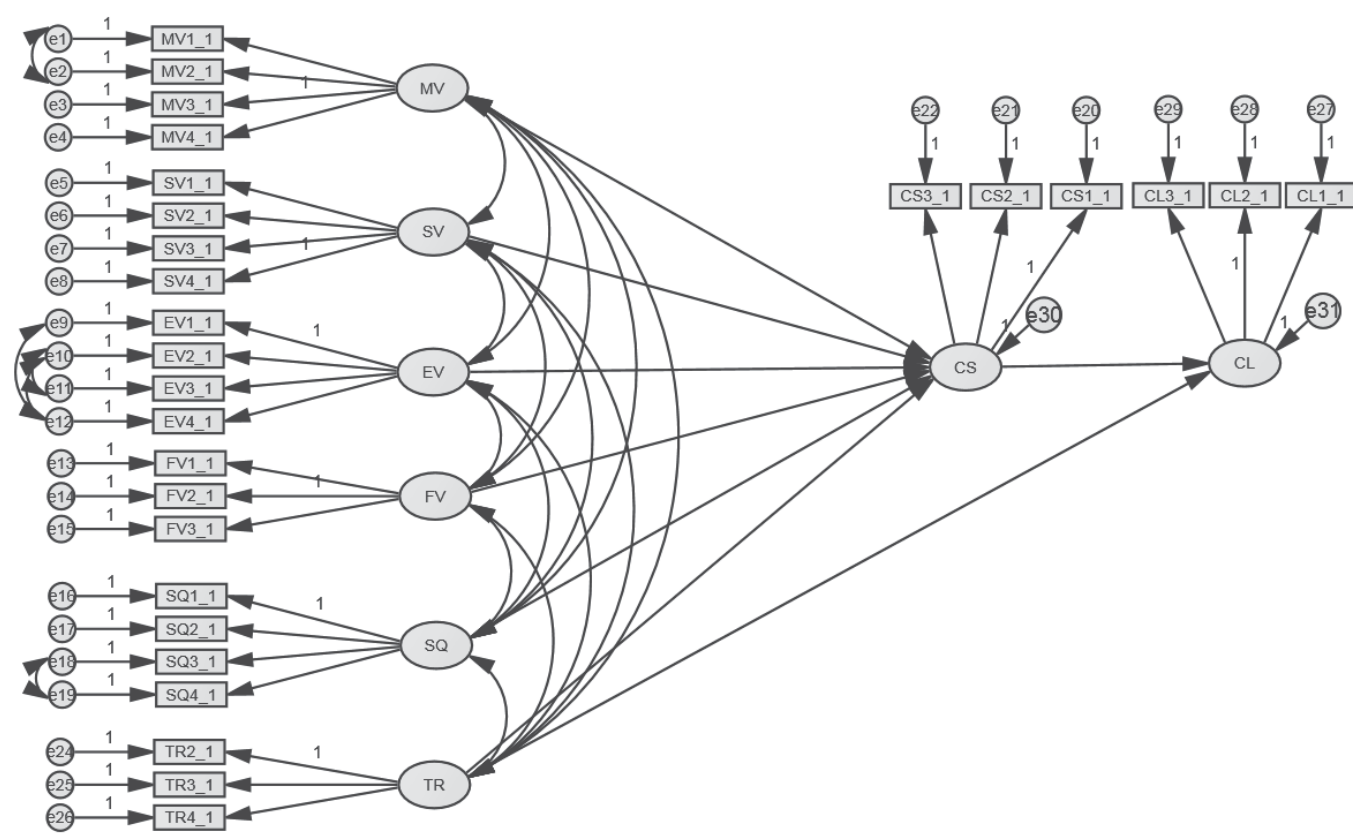


results (Hayes, 2013). Bootstrapping should be used to run the mediation analysis and to avoid limitations of the Baron and Kenny approach (Hayes, 2013; Jose, 2013).

In this study, only indirect effect was checked by using a user-defined indirect estimate by Amos. Table 4.6 shows the results of the indirect mediation. This clearly reflects that customer satisfaction mediates the correlation with trust, service quality, emotional value, and monetary value in a significant manner towards customer loyalty, which means that mediation is present.

TABLE 4.6: Mediation effect

\begin{tabular}{|l|c|c|c|}
\hline Relation & & $\begin{array}{c}\text { Indirect with } \\
\text { p-value }\end{array}$ & Mediation \\
\hline $\mathrm{TR} \rightarrow \mathrm{CS} \rightarrow \mathrm{CL}$ & & $0.07(0.001)$ & YES \\
\hline $\mathrm{SQ} \rightarrow \mathrm{CS} \rightarrow \mathrm{CL}$ & & $0.126(0.001)$ & YES \\
\hline $\mathrm{EV} \rightarrow \mathrm{CS} \rightarrow \mathrm{CL}$ & & $0.065(0.001)$ & YES \\
\hline $\mathrm{MV} \rightarrow \mathrm{CS} \rightarrow \mathrm{CL}$ & & $0.053(0.003)$ & YES \\
\hline $\mathrm{R}^{2}: \mathrm{CS}=0.41$ & $\mathrm{CL}=0.15$ & & \\
\hline
\end{tabular}

\section{DISCUSSION}

Pakistan's telecommunication sector is considered to be a complex, yet one of the fastest growing sectors in the country's economy. It promotes and generates subscribers' interest by introducing new offers, services, packages, and much more which mobile users find attractive and cannot resist engaging in. Thus, it is very challenging to judge customer loyalty and satisfaction in such a dynamic environment.

This study focused on some determinants and antecedents of customer loyalty and satisfaction that users find useful in terms of usage level of the service. This study identified the impact of service quality, trust, and customer perceived value on the satisfaction of the customer. Moreover, the effect of trust and satisfaction are also judged based upon customer loyalty. The relationship among variable was assessed by using path analysis in AMOS.

The results reveal that trust and satisfaction have a significant positive effect on customer loyalty. However, satisfaction was found to have the greatest impact on customer loyalty as its path coefficient value is 0.247 , whereas the coefficient of trust is 0.071 . Ribbink, Riel, Liljander and Streukens (2004) also found that trust has a weaker impact on customer loyalty compared to customer satisfaction. The significant result shows that trust and customer satisfaction are the antecedents that will eventually increase customer loyalty to the service provider. The result supports the findings of Yang and Peterson (2004), Kim and others (2004), Aydin and Özer (2005), Lin and Wang (2006), and Gerpott and others (2001). Therefore, cellular service providers need to make sure that they meet their customer needs and wants successfully in order to build a trustworthy relationship with them.

Trust and service quality were both found to have a significant and direct effect on customer satisfaction, thus confirming the results of Turel and Serenko (2006). In addition, it has been found that service quality has the greatest impact upon satisfaction among all antecedents having a path coefficient of 0.420 . It indicates that mobile users find service quality to be the most appealing element in forming their satisfaction towards loyalty (Wang, Lo \& Yang, 2004).

The emotional value and monetary value of perceived value constructs have a positive significant impact on satisfaction (Deng et al., 2010). This shows that monetary value and emotional value are important constructs through which customers seek to boost their satisfaction level. Furthermore, functional value was found to have a significant and negative correlation with customer satisfaction, while social value shows a negative insignificant correlation. The negative sign shows inverse correlation. These results support the findings of Dehghan and others (2015), Leelakulthanit and Hongcharu (2011), Loh and others (2015), and Williams and Soutar (2009). It may be due to the fact that most of our respondents fall in the 24 to 29 age group, who find more interest in the practical and technical benefits of functional value as well as in the acceptance of social value their 
service providers offer. As consumers are more tech-savvy nowadays, they want to keep in touch with the world anywhere and anytime via messages, voice chats, social packages, and video calls, especially after the inception of $3 G$ and $4 \mathrm{G}$ services. They may believe in the functional and social values of the service provider but may easily switch providers if they do not satisfy their desire or expectation of a particular service. Customers want maximum satisfaction from their service providers. However, due to intense market competition, service providers cannot fulfill all desired expectations. This may change the behavior and satisfaction level of the customer, and implies that their satisfaction will gradually decrease as they rely more on functional and social value.

\subsection{Managerial implications and limitations}

Achieving customer satisfaction and loyalty has become increasingly challenging for mobile operators. This research study provides an exclusive viewpoint and validates the comprehensive customer loyalty and satisfaction model in Pakistan. It also highlights the relationship of perceived value dimensions, service quality and trust on customer satisfaction and loyalty. The findings of the study provide a practical implication for mobile service providers as the research model explains that customer loyalty is well developed and managed through trust and customer satisfaction. Therefore, mobile service providers should invest in their services to earn the trust of customers and build a strong satisfaction level, as positive trust leads to a favorable level of satisfaction among customers and helps maintain their loyalty. Therefore, Pakistani service providers are advised to work on these psychological elements. Moreover, the PTA should regulate and manage such experts and authorities that enhance the marketing perspective of the tele- communication industry. It is recommended that PTA's promotional and marketing strategies be focused in a positive way that influences customer behaviors in a favorable manner. Cellular companies and organizations should maintain a relationship with customers by enhancing their services and staying in contact with them via e-mails to address and resolve their complaints. Responding promptly to subscribers will be essential in achieving customer satisfaction, which also enhances other factors such as trust, service quality, and perceived value constructs of emotional and monetary value. Furthermore, cellular organizations should invest in building a positive image of their brands to increase the loyalty of customers as the most important factor in maintaining a sustainable position to compete in an aggressive and challenging environment. Cellular companies in Pakistan ought to adopt such strategies that increase the satisfaction lev$\mathrm{el}$, as it is strongly related to building customer loyalty.

The research study was conducted mainly in Karachi, Pakistan. In view of numerous cultural differences between Pakistan and other countries, a future cross-cultural study can be conducted to enhance the understanding of loyalty and satisfaction antecedents. Also, this study is focused specifically on cellular services in Pakistan, but other service industries can be included to examine the differences among them. For future studies, it is suggested to investigate the relationship between loyalty and several other antecedents, such as corporate image, price, word of mouth (WOM), and switching cost. Control factors such as age, income, and gender should be considered to achieve a broader outcome. In a bid to strengthen the scientific contribution, a direct correlation of service quality and all customer value dimensions and their impact on loyalty may be examined in future research studies as well. 


\section{References}

1. Ali, J. F., Ali, I., Rehman, K., Yilmaz, A. K., Safwan, N., \& Afzal, H. (2010). Determinants of consumer retention in the cellular industry of Pakistan. African Journal of Business Management, 4(12), 24022408.

2. Allen, R. B., Hunter, J., \& Zeng, M. L. (2015). Digital Libraries: Providing Quality Information. 17 ${ }^{\text {th }}$ International Conference on Asia-Pacific Digital Libraries, ICADL 2015, Seoul, Korea.

3. Anderson, E. W., Fornell, C., \& Lehmann, D. R. (1994). Customer satisfaction, market share, and profitability: Findings from Sweden. The Journal of Marketing, 53-66.

4. Arif, I., Aslam, W., \& Ali, M. (2016). Students' dependence on smartphones and its effect on purchasing behavior. South Asian Journal of Global Business Research, 5(2), 285-302.

5. Aslam, W., Batool, M., \& Haq, Z. U. (2016). Attitudes and Behaviour of the Mobile Phones Users towards SMS Advertising: A Study in an Emerging Economy. Journal of Management Sciences, 3(1), 63-80.

6. Aslam, W., Ham, M., \& Arif, I. (2017). Consumer Behavioral Intentions towards Mobile Payment Services: An Empirical Analysis in Pakistan. Market-Tržište, 29(2), 161-176.

7. Aydin, S., \& Özer, G. (2006). How switching costs affect subscriber loyalty in the Turkish mobile phone market: An exploratory study. Journal of Targeting, Measurement and Analysis for Marketing, 14(2), 141-155.

8. Aydin, S., Özer, G., \& Arasil, Ö. (2005). Customer loyalty and the effect of switching costs as a moderator variable: A case in the Turkish mobile phone market. Marketing Intelligence \& Planning, 23(1), 89-103.

9. Bagozzi, R. P., \& Yi, Y. (1988). On the evaluation of structural equation models. Journal of the academy of marketing science, 16(1), 74-94.

10. Ball, D., Simões Coelho, P., \& Machás, A. (2004). The role of communication and trust in explaining customer loyalty: An extension to the ECSI model. European journal of marketing, 38(9/10), 1272-1293.

11. Baron, R. M., \& Kenny, D. A. (1986). The moderator-mediator variable distinction in social psychological research: Conceptual, strategic and statistical considerations. Journal of Personality and Social Psychology, 51, 1173-1182.

12. Bentler, P. M. (1990). Comparative fit indexes in structural models. Psycho-logical bulletin, 107(2), 238-246.

13. Browne, M. W., \& Cudeck, R. (1993). Alternative ways of assessing model fit. Sage Focus Editions, 154, 136-136.

14. Castaño, M. S., Méndez, M. T., \& Galindo, M. Á. (2015). The effect of social, cultural, and economic factors on entrepreneurship. Journal of Business Research, 68(7), 1496-1500.

15. Chang, M. K. (1998). Predicting unethical behavior: A comparison of the theory of reasoned action and the theory of planned behavior. Journal of business ethics, 17(16), 1825-1834.

16. Chin, W. (1998). The partial least squares approach for structural equation modeling. In: G. A. Marcoulides (ed.), Modern methods for business research (pp. 295-336). Mahwah, NJ: Lawrence Erlbaum Associates.

17. Chinomona, R., \& Pretorius, M. (2011). Major dealers' expert power in distribution channels. South African Journal of Economic and Management Sciences, 14(2), 170-187.

18. Chinomona, R., Masinge, G., \& Sandada, M. (2014). The influence of e-service quality on customer perceived value, customer satisfaction and loyalty in South Africa. Mediterranean Journal of Social Sciences, 5(9), 331-341.

19. Chiou, J-S., \& Droge, C. (2006). Service quality, trust, specific asset investment, and expertise: Direct and indirect effects in a satisfaction-loyalty framework. Journal of the Academy of Marketing Science, 34(4), 613-627. 
20. Dehghan, A. N., Alizadeh, H., \& Mirzaei-Alamouti, S. (2015). Exploring the customer perceived values as antecedent of purchase behavior. Serbian Journal of Management, 10(2), 173-188.

21. Deng, Z., Lu, Y., Wei, K. K., \& Zhang, J. (2010). Understanding customer satisfaction and loyalty: An empirical study of mobile instant messages in China. International Journal of Information Management, 30(4), 289-300.

22. Eid, M. I. (2011). Determinants of e-commerce customer satisfaction, trust, and loyalty in Saudi Arabia. Journal of electronic commerce research, 12(1), 78-93.

23. Fishbein, M., \& Ajzen, I. (1975). Belief, Attitude, Intention, and Behavior: An Introduction to Theory and Research. Reading, MA: Addison-Wesley.

24. Fornell, C., \& Larcker, D. F. (1981). Evaluating structural equation models with unobservable variables and measurement error. Journal of marketing research, 18(1), 39-50.

25. Friedrich, R., Grone, F., Holbling, K., \& Peterson, M. (2009). The March of Mobile Marketing New Chances for Consumer Companies, New Opportunities for Mobile Operators. Journal of Advertising Research, 49(1), 54-61.

26. Garbarino, E., \& Johnson, M. S. (1999). The different roles of satisfaction, trust, and commitment in customer relationships. Journal of Marketing, 63, 70-87.

27. Gefen, D. (2002). Customer loyalty in e-commerce. Journal of the Association for Information Systems, 3(1), 27-51.

28. Gerpott, T. J., Rams, W., \& Schindler, A. (2001). Customer retention, loyalty, and satisfaction in the German mobile cellular telecommunications market. Telecommunications policy, 25(4), 249-269.

29. Gitomer, J. (1998). Customer Satisfaction is Worthless, Customer Loyalty Is Priceless. Houston, TX: Bard Press.

30. Guo, L., Xiao, J. J., \& Tang, C. (2009). Understanding the psychological process underlying customer satisfaction and retention in a relational service. Journal of Business Research, 62(11), 11521159.

31. Hair, J. F., Anderson, R. E., Babin, B. J., \& Black, W. C. (2010). Multivariate data analysis: A global perspective. Upper Saddle River, NJ: Pearson.

32. Hair, J. F., Anderson, R. E., Tatham, R. L., \& Black, W. C. (1998). Multivariate Data Analysis. Upper Saddle River, NJ: Prentice Hall.

33. Hancock, G. R., \& Mueller, R. O. (2001). Rethinking construct reliability within latent variable systems. In: R. Cudeck, S. du Toit \& D. Sörbom (eds.), Structural equation modeling: Present and future - A Festschrift in honor of Karl Jöreskog (pp. 195-216). Lincolnwood, IL: Scientific Software International.

34. Hansen, T., Jensen, J. M., \& Solgaard, H. S. (2004). Predicting online grocery buying intention: a comparison of the theory of reasoned action and the theory of planned behavior. International Journal of Information Management, 24(6), 539-550.

35. Hart, C. W., \& Johnson, M. D. (1999). Growing the trust relationship. Marketing Management, 8(1), 9-19.

36. Hayes, A. F. (2013). Introduction to mediation, moderation, and conditional process analysis: A regression-based approach. New York, NY: Guilford Press.

37. Hsu, C. L., \& Lu, H. P. (2007). Consumer behavior in online game communities: A motivational factor perspective. Computers in Human Behavior, 23(3), 1642-1659.

38. Huang, C. C., Wang, Y. M., Wu, T. W., \& Wang, P. A. (2013). An empirical analysis of the antecedents and performance consequences of using the moodle platform. International Journal of Information and Education Technology, 3(2), 217.

39. Hudson, H. E. (2013). From rural village to global village: Telecommunications for development in the information age. New York, NY: Routledge. 
40. Ishaq, I. M. (2012). Perceived value, service quality, corporate image and customer loyalty: Empirical assessment from Pakistan. Serbian Journal of Management, 7(1), 25-36.

41. Jahanzeb, S., Fatima, T., \& Khan, M. B. (2011). An empirical analysis of customer loyalty in Pakistan's telecommunication industry. Journal of Database Marketing \& Customer Strategy Management, 18(1), 5-15.

42. Jayanthi, M., \& Rajandran, K. V. R. (2017). A Study On Challenges Of Multicultural Team Members Of It Sector. International Journal of Management, 8(1), 111-118.

43. John, J. (2011). An analysis on the customer loyalty in telecom sector: Special reference to Bharath Sanchar Nigam limited, India. African Journal of Marketing Management, 3(1), 1-5.

44. Jose, P. E. (2013). Doing statistical mediation and moderation. New York, NY: Guilford Press.

45. Kassim, N. M., \& Abdullah, N. A. (2008). Customer Loyalty in e-Commerce Settings: An Empirical Study. Electronic Markets, 18(3), 275-290.

46. Karjaluoto, H., Jayawardhena, C., Leppäniemi, M., \& Pihlström, M. (2012). How value and trust influence loyalty in wireless telecommunications industry. Telecommunications Policy, 36(8), 636-649.

47. Karjaluoto, H., Mattila, M., \& Pento, T. (2002). Factors underlying attitude formation towards online banking in Finland. International journal of bank marketing, 20(6), 261-272.

48. Khan, M. M., \& Fasih, M. (2014). Impact of Service Quality on Customer Satisfaction and Customer Loyalty: Evidence from Banking Sector. Pakistan Journal of Commerce \& Social Sciences, 8(2), 331354.

49. Kim, D. J., Ferrin, D. L., \& Rao, H. R. (2009). Trust and satisfaction, two stepping stones for successful e-commerce relationships: A longitudinal exploration. Information Systems Research, 20(2), 237-257.

50. Kim, M. K., Park, M. C., \& Jeong, D. H. (2004). The effects of customer satisfaction and switching barrier on customer loyalty in Korean mobile telecommunication services. Telecommunications policy, 28(2), 145-159.

51. Kotler, P., Keller, K. L., Koshy, A., \& Jha, M. (2009). Marketing management: A South Asian perspective (13 ${ }^{\text {th }}$ ed.). New Delhi: Pearson Prentice Hall.

52. Kyoon Yoo, D., \& Ah Park, J. (2007). Perceived service quality: Analyzing relationships among employees, customers, and financial performance. International Journal of Quality \& Reliability Management, 24(9), 908-926.

53. Lai, F., Griffin, M., \& Babin, B. J. (2009). How quality, value, image, and satisfaction create loyalty at a Chinese telecom. Journal of Business Research, 62(10), 980-986.

54. Lee, M. K. O., \& Turban, E. (2001). A trust model for consumer Internet shopping. International Journal of Electronic Commerce, 6(1), 75-91.

55. Lee, T. (2005). The impact of perceptions of interactivity on customer trust and transactions in mobile commerce. Journal of Electronic Commerce Research, 6(3), 165-180.

56. Leelakulthanit, O., \& Hongcharu, B. (2011). Factors that impact customers satisfaction: Evidence from the. Thailand mobile cellular network industry. International Journal of Management and Marketing Research, 4(2), 67-76.

57. Liao, C., Palvia, P., \& Chen, J-L. (2009). Information technology adoption behavior life cycle: Toward a technology continuance theory (TCT). International Journal of Information Management, 29(4), 309-320.

58. Lin, H. H., \& Wang, Y. S. (2006). An examination of the determinants of customer loyalty in mobile commerce contexts. Information \& management, 43(3), 271-282.

59. Loh, M., Ahmad, M., Kadir, S. A., \& Alam, S. S. (2015). Influence of Customer Values and Self-Image Congruity on Customer Behavior-Based CRM Performance. Management and Marketing Journal, 13(1), 23-44. 
60. Lu, H., \& Lin, J. C. C. (2002). Predicting customer behavior in the market-space: a study of Rayport and Sviokla's framework. Information \& Management, 40(1), 1-10.

61. Luarn, P., \& Lin, H. H. (2003). A Customer Loyalty Model for E-Service Context. Journal of Electronic Commerce Research, 4(4), 156-167.

62. Mahjoub, H., \& Naeij, A. K. (2015). The Impact of Prestige, Consumer Personality and Self-Concept on Brand Loyalty. The International Journal of Business \& Management, 3(4), 392.

63. Malhotra, N. K., \& Dash, S. (2011). Marketing Research: An applied Orientation (6 ${ }^{\text {th }}$ ed.). New Jersey, NJ: Pearson Education.

64. McKnight, D. H., \& Chervany, N. L. (2002). What trust means in e-commerce customer relationships: An interdisciplinary conceptual typology. International Journal of Electronic Commerce, 6(2), 35-59.

65. Molina, L. M., Llorens-Montes, J., \& Ruiz-Moreno, A. (2007). Relationship Between quality management practices and knowledge transfer. Journal of Operations Management, 25(3), 682-701.

66. Moreira, A. C., Moreira, A. C., Silva, P. M., Silva, P. M., Moutinho, V. F., \& Moutinho, V. F. (2016). Differences between stayers, switchers, and heavy switchers: A study in the telecommunications service market. Marketing Intelligence \& Planning, 34(6), 843-862.

67. Morgan, R. M., \& Hunt, S. (1994). The Commitment-Trust Theory of Relationship Marketing. Journal of Marketing, 58(3), 20-38.

68. Muhammad, I., Shamsudin, M. F., \& Hadi, N. U. (2016). How Important Is Customer Satisfaction? Quantitative Evidence from Mobile Telecommunication Market. International Journal of Business and Management, 11(6), 57-69.

69. Nunnally, J. (1978). Psychometric theory (2nd ed.). New York, NY: McGraw-Hill.

70. Parasuraman, A., \& Grewal, D. (2000). The Impact of Technology on the Quality-Value-Loyalty Chain: A Research Agenda. Journal of the Academy of Marketing Science, 28, 168-170.

71. Qayyum, A., Ba Khang, D., \& Krairit, D. (2013). An analysis of the antecedents of loyalty and the moderating role of customer demographics in an emerging mobile phone industry. International Journal of Emerging Markets, 8(4), 373-391.

72. Rajan, C. A., \& Baral, R. (2015). Adoption of ERP system: An empirical study of factors influencing the usage of ERP and its impact on end user. IIMB Management Review, 27(2), 105-117.

73. Rasheed, F. A., \& Abadi, M. F. (2014). Impact of service quality, trust and perceived value on customer loyalty in Malaysia services industries. Procedia-Social and Behavioral Sciences, 164, 298-304.

74. Ribbink, D., Riel, A. V., Liljander, V., \& Streukens, S. (2004). Comfort your online customer: Quality, trust and loyalty on the internet. Managing service quality, 14(6), 446-456.

75. Rust, R. T., Lemon, K. N., \& Zeithaml, V. A. (2001). Driving Customer Equity: How Customer Lifetime Value Is Reshaping Corporate Strategy. New York, NY: The Free Press.

76. Santouridis, I., \& Trivellas, P. (2010). Investigating the impact of service quality and customer satisfaction on customer loyalty in mobile telephony in Greece. The TQM Journal, 22(3), 330-343.

77. Sheth, J. N., Newman, B. I., \& Gross, B. I. (1991). Consumption values and market choice. Cincinnati, $\mathrm{OH}$ : South Western Publishing.

78. Shujaat, S., Syed, N. A., \& Ahmed, U. (2015). Factors behind Brand Switching in Telecommunication Industry of Pakistan. IBT Journal of Business Studies, 11(2), 29-40.

79. Siau, K., \& Shen, Z. (2003). Building customer trust in mobile commerce. Communications of the ACM, 46(4), 91-95.

80. Sirdeshmukh, D., Singh, J., \& Sabol, B. (2002). Consumer trust, value, and loyalty in relational exchanges. Journal of marketing, 66(1), 15-37.

81. Sweeny, J. C., \& Soutar, G. N. (2001). Consumers perceived value: The development of a multiple item scale. Journal of Retailing, 77(2), 203-220. 
82. Tabachnick, B. G., \& Fidell, L. S. (2007). Using Multivariate Statistics (5 $5^{\text {th }}$ ed.). New York, NY: Allyn and Bacon.

83. Turel, O., \& Serenko, A. (2006). Satisfaction with mobile services in Canada: An empirical investigation. Telecommunications policy, 30(5), 314-331.

84. Venetis, K. A., \& Ghauri, P. N. (2000). The importance of service quality on customer retention: an empirical study of business service relationships. Proceedings of the Marketing in a Global Economy Conference, Buenos Aires, June (Vol. 28).

85. Wang, Y., Lo, H. P., \& Yang, Y. (2004). An integrated framework for service quality, customer value, satisfaction: Evidence from China's telecommunication industry. Information systems frontiers, 6(4), 325-340.

86. Wang, Y-S., Lin, H-H., \& Luarn, P. (2006). Predicting consumer intention to use mobile service. Information Systems Journal, 16(2), 157-179.

87. Williams, P., \& Soutar, G. N. (2009). Value, satisfaction and behavioral intentions in an adventure tourism context. Annals of Tourism Research, 36(3), 413-438.

88. Yang, Z., \& Peterson, R. T. (2004). Customer perceived value, satisfaction, and loyalty: The role of switching costs. Psychology \& Marketing, 21(10), 799-822. 